Milena Fornazarič ${ }^{1}$, Jani Toroš²

'Visoka šola za poslovne vede, Ljubljana

2Innovative Management Institute, Ljubljana

\title{
Relationship between Behavioural Factors and Colour Preferences for Clothing
}

Povezanost vedenjskih značilnosti z izbiro barv oblačil

\author{
Original Scientific Article/lzvirni znanstveni članek \\ Received/Prispelo 05-2017 • Accepted/Sprejeto 09-2017
}

\begin{abstract}
The colour of clothing plays an important role in one's emotional reaction and the selection of clothes, which in turn effects design, the fashion industry and sales. In our behavioural research involving the Slovenian population regarding the selection of colours, we used the results of opportunity sampling, i.e. a web survey using a sample of 204 respondents, who were invited to participate in the research using an email list sampling method. Our aim was determine how demographic and behavioural characteristics affect colour preferences for clothing. Demographic characteristics are not important in terms of the behaviour of different segments of the population, except with regard to gender. Nevertheless, we can use the results of the survey to make a correlation between colour and consumer characteristics. Those who are fond of the colour beige follow fashion trends more closely than the others, while the colour white is associated with those who follow fashion on web and in online shopping. On the contrary, consumers who prefer pink and purple primarily buy clothes in fashion shops. Those who prefer brown and beige enjoy the shopping experience more than others, while lovers of the colour pink are less inclined to buy clothes during sales than others. Consumers who prefer the colour blue are predominant in fitting shops, while those who prefer the colour black do not to buy clothes on Saturdays. Lovers of the colour blue stand out in terms of spending, while people who are fond of the colour white spend the most, although they prefer to buy less expensive clothes. People drawn to the colour grey prefer to buy less expensive jackets, while women who prefer the colour green also buy less expensive jackets. We recommend expanding the scope of the research to include historical determinants, fashion patterns, marketing communication and fashion brands, as well as other, more rational and speculative motives associated with a subject's personality.

Keywords: psychology of colours, behaviour, colours of clothes, Slovenia
\end{abstract}

\section{Izvleček}

Barva oblačila ima pomembno vlogo v posameznikovem čustvenem odzivu na oblačilo, kar posledično vpliva na modno industrijo, oblikovanje, proizvodnjo in prodajo oblačil. V raziskavi o vplivu vedenjskih značilnosti Slovencev pri izbiri barv smo uporabili rezultate spletne ankete na vzorcu 204 respondentov. Pri vzorčenju je bil uporabljen priložnostni vzorec oziroma način pridobivanja respondentov z individualnimi vabili po metodi seznama e-poštnih naslovov - E-mail list samples. Preverjali smo, kako demografske in vedenjske značilnosti vplivajo na preferenco barve oblačila. Demografske značilnosti niso pomembne pri vedenju posameznih segmentov, razen pri spolu, lahko pa so izsledki raziskave povezava med barvo in značilnostmi potrošnikov. Ljubitelji bež barv bolj sledijo modnim smernicam kot drugi. Bela barva je povezana s sledenjem modi na svetovnem spletu, kar velja tudi za spletne nakupe. Nasprotno pa ljubitelji roza in vijoličastih barv oblačil nakupujejo predvsem v prodajalnah. Ljubitelji rjavih in bež barv bolj kot drugi uživajo pri nakupovanju, medtem ko tisti, ki imajo radi oblačila roza barv, manj kupujejo na razprodajah kot drugi. Pri pomerjanju oblačil so najdoslednejši ljubitelji modre barve, ljubitelji črne pa ne želijo

Corresponding author/Korespondenčni avtor:

Assist Prof dr. Jani Toroš

E-mail: jani.toros@imi-institute.org
Tekstilec, 2018, 61(1), 4-14

DOI: 10.14502/Tekstilec2018.61.4-14 
nakupovati ob sobotah. Pri porabi denarja za oblačila izstopajo respondenti, ki so izbrali modro. Tisti, ki so izbrali belo, so najbolj zapravljivi. Pri analizi zneskov, ki jih respondenti po navadi namenijo za nakup oblačila, smo ugotovili, da ljubitelji belih oblačil kupujejo obleke v nižjem cenovnem razredu, prav tako je siva povezana z nakupom suknjičev. Ljubitelji sive kupujejo suknjiče v nižjem cenovnem razredu. Pri ženskah ima podoben vpliv zelena barva. Ženske, ki imajo rade zeleno, kupujejo jakne v nižjem cenovnem razredu. Raziskovanje bi kazalo razširiti na upoštevanje zgodovinskih determinant, mode in tržnega komuniciranja, blagovne znamke ali celo kakšnega drugega, bolj racionalnega in preračunljivega motiva, ki je povezan z osebnostjo posameznika.

Ključne besede: psihologija barv, vedenje, barva oblačila, Slovenija

\section{Introduction}

\subsection{Importance of colours for people}

Psychologists have claimed for years that colours play a more important role in people's lives than words, particularly during the period when an individual matures and transitions from childhood to adulthood, and expresses that maturity through the choice of different colour groups. The selection of an outfit's colour is important to women in particular, and is linked to a woman's age, character, body shape, body colour (e.g. skin, hair and eyes), height (i.e. bright and light colours can optically lengthen a body, while the colour black accentuates a body's silhouette and can even emphasise certain imperfections, such as wide hips), the occasion and lighting conditions when an outfit is to be worn, the type of fabric, etc. Each and every individual is unique and special with regard to such characteristics. The simplest general rule, however, is that warm colours suit people with warm skin tones, while people with cool skin tones prefer cool colours when choosing clothes [1]. People also have different personalities that range from calm and introverted to gregarious and even aggressive. People with a strong personality are said to wear strong, bright colours.

\subsection{Theoretical background}

Designers in the fields of architecture, marketing, the automotive industry, fashion, etc. are acutely aware of the relationship between colours and different human needs [2]. In general, studies that investigate the relationship between colours and people's emotional response can be divided into two groups: The first group encompasses studies that address colour preferences (such as 'I like' or 'I don't like'), while the second group includes studies of the relationship between specific characteristics that we ascribe to certain colours and the colours themselves (for example, a colour is warm or cool, heavy or light, etc.). The two described two groups can also be combined [2]. The characteristics that affect the emotional response to a colour also depend on the materials, lighting conditions, background and the shade of a colour, as well as the gender, age and nationality of the observer. Although it is usually claimed that an emotional response to a colour depends on the individual and is culturally formed, these are set rules and trends. For this reason, some researchers have tried to develop mathematical models in an attempt to predict people's responses to colours [2]. We are first and foremost interested in those studies that examine clothing, the response of potential consumers to certain colours and the emotions associated with those colours. Studies show that responses to colours are systematic and predictable [3]. For example, cool colours have a calming effect, while warm colours have a stimulating effect. Most studies use colour scales that are observed by respondents in a neutral environment. However, the circumstances with which we associate a specific colour are also of importance (e.g. cultural and language context, the type of object that is observed and the surroundings) [3].

In addition to type, the other characteristics of a colour are also important. The colour of an item of clothing plays an important role in an individual's emotional response to that item, which in turn has an effect on the fashion industry, designers, manufacturers, and retailers. Both fashion designers and those who follow fashion believe that clothes that are different shades of the same colour but equally bright are not equally pleasing to the eye. Thus, among characteristics such as brightness, the shade of colour saturation and colour luminosity, brightness is the most important in terms of choosing an article of clothing [4]. The brightness of an outfit's colour can be described as the fabric's quality to absorb different quantities of light. Studies show that individuals have a higher ability to differentiate between brightness than different 
colour shades [4], which confirms the claim that people choose their clothes according to colour brightness. Colour brightness has a significant effect on the psychological perception of clothes, yet itself depends on the type of fabric, the structure and property of fibres and the applied dyeing method. Generally speaking, brighter colour shades evoke in people a feeling of energy, purity and light. Medium-bright colour shades evoke ideas of conservatism, stability and normality, while colour shades of lesser brightness imbue people with feelings of simplicity, plainness, depression and definitiveness [4]. These findings are important when making purchasing decisions, such as whether to choose clear colours or colours to which black and white have been added, as consumers respond differently to the two.

E-commerce is becoming increasingly established in the fashion industry, but a problem arises when the colours of clothes that potential buyers see on their screens do not match the colours of the actual purchased products. This can lead to dissatisfaction among consumers, the return of products and losses for suppliers. Reasons for the inaccurate rendering of colours on the screen relative to reality include different temperatures, the lighting of photo shoots and background lighting. Because of the different temperatures of illumination sources, different shades of a colour are rendered on the computer screen, although the same lighting was used on an object [5]. Professional photographers can eliminate different colour shades with a special (time-consuming) method that uses light sources of the same temperature. There are algorithms, or programs, used today by online stores to achieve a more efficient and less time-consuming way of photographing objects [5]. The human eye perceives colours the same way, no matter the light source (for example, an apple is green whether it is lit by fluorescent light or daylight), while the same does not hold true for cameras. Digital photographs can be manipulated using programs that are based on the assumption that the colour white is white no matter the light source [5], while the same holds true for mobile applications. Technology in this field is advancing at a rapid pace.

\subsubsection{Meaning of specific colours and human emotions}

Colours play an important role in the development of a brand's personality, as they strengthen the buyer's emotional satisfaction at the time of a purchase, meaning they can also increase the likelihood of a purchase [6]. Colours are part of a brand or company's corporate identity and an important element of distinction when a brand is positioned on the market next to its competitors. Colours represent the key element of logos, packaging, advertisements and communication, and have a significant effect on the consumer's emotional response. Studies are turning away from the mere aesthetic judgement of colours and are focusing on the functionality of colours in the field of marketing, where colours serve a certain function (meaning) in a specific environment [7], and affect human decisions [8]. Cool colours, such as green, blue and white, are equated with peace, tenderness and calmness, whereas warm colours, such as yellow, gold, red, orange and purple, signify action, sharpness and 'hotness' [9]. In general, people are born with the ability to respond to colours, and even a child of just two years [10] can distinguish between them. As an individual matures into a teenager, they develop their own relationship to colours, which does not tend to change in the latter stages of life, except in the event of drastic personal, cultural, societal or global changes. Women have a more heightened sense of colours than men, and tend to have a favourite colour [11]. The same authors give a general overview of colours and their meaning:

- Red is associated with power, energy, warmth, Christmas, love, excitement, passion, activity, intensity, danger, wishes, violence and anger. Men rarely tend to own red clothing, except perhaps as sportswear. The colour red is used in restaurants and casinos because it is said to have the power to induce the loss of a person's sense of time.

- Blue is the colour of trust and dependence, often chosen by people who prefer solitude. It is a cool colour, and represents calmness, stability, harmony, trust, oneness, masculinity, conservatism, security, authority, order, purity, belonging, coldness, the sky, water and technology. It suppresses appetite, and lowers body temperature and blood pressure. It is the colour of the business world (most company logos in the US are blue), as it represents reliability. The authors contend that, globally speaking, different shades of the colour blue are the favourite colour in the world.

- Black is the colour of dignity and complexity, and is the most popular colour for outfits. We associate the colour with mourning and death, yet also with elegance, power, sexuality, wealth, secrecy, 
fear, evil, misfortune, sadness and anger. It is the most common colour for business outfits.

- White is the colour we see when all colours are in complete balance. It represents purity, simplicity, cleanliness, peace, joy, preciseness, innocence, youth, birth, winter, snow, the holy, sterility, death and marriage. It is used extensively in the world of medicine and among intellectuals.

- Purple represents royalty, spirituality, wealth, art, creativity, intricacy, supremacy, secrets, wisdom, change, enlightenment, cruelty, arrogance and the exotic, and is very popular among young people. It is perceived as the most reviled or most loved colour among other age groups.

- Green is one of the most common and popular colours. It represents nature, health, the environment, happiness, youth, safety, spring, fertility, generosity, Christmas, jealousy, naivety, envy, money, etc. It has healing powers and is often used in operating rooms.

- Yellow is the colour of joy, warmth, happiness, optimism, hope, idealism, dishonesty, betrayal, jealousy, cowardice, success, gentleness and spirituality. We often associate it with cheapness and jealousy.

- Orange is a safe colour that attracts attention. It is a combination of yellow and red, yet is less powerful than red. It represents energy, balance, warmth and adventurousness. We associate it with autumn and simplicity, which is why it is not a colour for expensive, luxury products. It is the favourite colour of the Netherlands.

- Brown is a neutral colour, and is associated with nature, earth, warmth, reliability, comfort, neutrality, harmony, home and simplicity. It is a colour with strong and positive ties to food and wood.

- Grey is associated with indecisiveness, but also intelligence, humility, boundlessness, security, sadness, practicality, dependence and elegance. It is a popular colour among businesswomen.

Depending on their surroundings, people perceive colours differently. The significance of specifically chosen colours for identical objects varies between different environments. In terms of contemporary products (e.g. computers, clocks and telephones), cultural differences dissipate completely. Nevertheless, colours are extremely important when it comes to clothes, shoes, hats, glasses, backpacks and bathrobes - simply put - fashion. How are colours and fashion chosen in Slovenia and among its inhabitants?

\subsection{Objectives and hypothesis of the study}

Our objective was to determine how demographic and behavioural characteristics affect colour preferences for clothes.

Two hypotheses were developed in our research:

H1: There is a statistically significant relationship between demographic characteristics and preference for a certain outfit colour.

$\mathrm{H} 2$ : There is a statistically significant relationship between behavioural characteristics and preference for a certain outfit colour.

Behavioural characteristics were divided into subgroups:

- manner of dressing

- relationship to clothing and fashion

- way of purchasing clothing

- financial means consumers spend on clothing.

\section{Methodology}

Our study on the effect of behavioural characteristics on the selection of colours used the results of an online survey performed using an opportunity sample of 204 respondents comprising 146 women and 58 men. Sampling was carried out by sending respondents individual invitations via email list samples [12]. We ask closed question about the manner of dressing, respondents' relationship to clothing and fashion, the way of purchasing clothing, the financial means consumers spend on clothing and the colours of clothes they prefer.

Our data analysis employed a cross tabulation method, and the Pearson chi-square test using SPSS (Statistical Package for the Social Sciences) software as the quantitative research method appropriate for analysing the relationship between colour preference and consumer behavioural characteristics.

\section{Results}

Data regarding consumer behavioural characteristics are presented in Table 1. In addition to demographic characteristics, we studied behavioural characteristics regarding consumers' relationship to clothing, their relationship to dressing and the financial means they spend on clothing. We also asked which colour of clothing individuals prefer, and limited the answer to four selected colours. 
In general, the most commonly chosen colour was black, which does not surprise us. While long ago mostly older women wore black, many young people wear black today. Black is followed in popularity by blue and white, while just under $40 \%$ of respondents prefer grey, as seen in Table 1.

Table 1: Selection of popular colours for clothing

\begin{tabular}{|l|r|r|c|}
\hline \multicolumn{1}{|c|}{ Colour } & \multicolumn{1}{c|}{ n } & Sum & Freq. [\%] \\
\hline Black & 204 & 175 & 85.8 \\
\hline Blue & 204 & 100 & 49.0 \\
\hline White & 204 & 92 & 45.1 \\
\hline Grey & 204 & 79 & 38.7 \\
\hline Red & 204 & 54 & 26.5 \\
\hline Beige & 204 & 54 & 26.5 \\
\hline Brown & 204 & 40 & 19.6 \\
\hline Colour combination & 204 & 31 & 15.2 \\
\hline Violet & 204 & 27 & 13.2 \\
\hline Pink & 204 & 26 & 12.7 \\
\hline Green & 204 & 26 & 12.7 \\
\hline Blue-Green & 204 & 13 & 6.4 \\
\hline Orange & 204 & 9 & 4.4 \\
\hline Yellow & 204 & 9 & 4.4 \\
\hline Khaki & 204 & 8 & 3.9 \\
\hline
\end{tabular}

\subsection{Demographic effect on the colour preference of clothing \\ 3.1.1 Gender}

We did not identify any statistically significant differences associated with the colours black, white and grey. Both genders exhibited the same configuration of preferences for black and white tones, as seen in Table 2.

Table 2: Preference of colours according to gender

\begin{tabular}{|l|c|c|c|}
\hline \multirow{2}{*}{ Gender } & \multicolumn{3}{|c|}{ Colour preference [\%] } \\
\cline { 2 - 4 } & Black & Grey & White \\
\hline Female & 85.60 & 35.60 & 41.40 \\
\hline Male & 86.20 & 46.60 & 45.10 \\
\hline
\end{tabular}

Choosing black and white seems to be a reliable and safe option. We found that the colour blue is also a more popular colour, yet preference for this colour is not equally distributed between genders.
We identified a significant difference (chi-squared $=$ 10.76 and $\mathrm{P}=0.001$ ), showing a greater preference for blue by men than by women.

Table 3: Preference of the colour blue according to gender

\begin{tabular}{|l|c|}
\hline \multirow{2}{*}{ Gender } & Colour preference [\%] \\
\cline { 2 - 2 } & Blue \\
\hline Female & 41.80 \\
\hline Male & 67.20 \\
\hline
\end{tabular}

The preference of men and women for other colours is more or less equal. It is evident from Tables 4 and Table 5 which colours are more popular than others.

Table 4: More popular colours according to gender

\begin{tabular}{|l|c|c|c|c|c|}
\hline \multirow{2}{*}{ Gender } & \multicolumn{5}{|c|}{ Colour preference [\%] } \\
\cline { 2 - 6 } & Red & Brown & $\begin{array}{c}\text { Combi- } \\
\text { nation }\end{array}$ & Green & Violet \\
\hline Female & 27.4 & 18.5 & 13.0 & 11.6 & 15.8 \\
\hline Male & 24.1 & 22.5 & 20.7 & 15.5 & 6.9 \\
\hline
\end{tabular}

Table 5: Less popular colours according to gender

\begin{tabular}{|l|c|c|c|c|}
\hline \multirow{2}{*}{ Gender } & \multicolumn{4}{|c|}{ Colour preference [\%] } \\
\cline { 2 - 5 } & $\begin{array}{c}\text { Blue- } \\
\text { green }\end{array}$ & Orange & Yellow & Khaki \\
\hline Female & 4.8 & 4.1 & 4.1 & 4.1 \\
\hline Male & 10.3 & 5.2 & 5.2 & 3.4 \\
\hline
\end{tabular}

Pink (chi-squared 11.9 and $\mathrm{P}=0.001$ ) and beige (chisquared 6.7 and $\mathrm{P}=0.01$ ) are two predominantly female colours (Table 6).

Table 6: Preference of the colour pink and beige according to gender

\begin{tabular}{|l|c|c|}
\hline \multirow{2}{*}{ Gender } & \multicolumn{2}{|c|}{ Prefer colour [\%] } \\
\cline { 2 - 3 } & Pink & Beige \\
\hline Female & 17.80 & 31.50 \\
\hline Male & 0.00 & 13.80 \\
\hline
\end{tabular}

The traditional distinction between male (blue) and female (pink) colours was verified in this study. 
Evidently, colour preference is passed on subconsciously at birth, and accompanies every individual, even in later years. We were surprised by the findings regarding men's attitude towards beige. We assume that bright brown tones are very popular among both genders in the summer months.

\subsubsection{Age, education and income}

We found no significant differences with regard to individuals' colour preference for clothes when we crossed the variables of age (six groups), education (three groups) and income (three groups). We conclude from this that, apart from gender, other demographic characteristics do not affect colour preference.

\subsection{Behavioural characteristics}

Group segments according to the manner of dressing.

We also analysed the relationship between an outfit's colour and the way people dress. During the preliminary quantitative survey, we found that people are not very aware of different fashion styles. Terms such as sporty, sporty-elegant, formal, informal, casual and other terms found in fashion literature, such as sports clothing, leisure wear, casual look, casual elegant attire, casual business look, daily business attire and traditional business look [13], were generally too complicated for the majority of the respondents, and most had different perceptions of the aforementioned terms.

\subsubsection{Manner of dressing}

We therefore divided the respondents into three groups according to the clothes they usually wear to work on a daily basis. We defined the following styles:

- sportswear

- relaxed casual look

- formal look.

In the online survey, we added images to explain to the respondents in detail what we meant by different styles, so that they would not confuse different terms. The groups dress differently, yet we found no significant differences in colour choice. Although one would expect that more formal clothes would be associated with black and white colour combinations, no significant differences were identified, at least in this study.

\subsubsection{Importance of clothing in the eyes of consumers}

Among the respondents who answered the question, 'What is your relationship to the clothes you wear?' with the answers in the Table 7, we did not identify any significant differences it terms of colour preference.

Table 7: Relationship to clothing

\begin{tabular}{|l|c|}
\hline \multicolumn{1}{|c|}{ Relationship to clothing } & Freq. [\%] \\
\hline Very important & 46.10 \\
\hline Sometimes important & 45.10 \\
\hline Not important & 8.80 \\
\hline
\end{tabular}

The same holds true for the question regarding how people dress in the morning, where we divided respondents into four different groups (Table 8).

Table 8: How respondents dress in the morning

\begin{tabular}{|l|c|}
\hline \multicolumn{1}{|c|}{$\begin{array}{c}\text { How do you dress in the } \\
\text { morning? }\end{array}$} & Freq. [\%] \\
\hline $\begin{array}{l}\text { I usually prepare my outfit the } \\
\text { night before }\end{array}$ & 13.20 \\
\hline $\begin{array}{l}\text { I choose my outfit spontaneously, } \\
\text { based on how I feel }\end{array}$ & 73.50 \\
\hline I wear the same outfit every day & 5.40 \\
\hline I wear whatever I see first & 7.80 \\
\hline
\end{tabular}

\subsubsection{Fashion trends}

People who favoured beige colours for their outfits followed fashion trends more often than others. We found when crossing the variable questions, 'Do you follow fashion trends when choosing clothes?' and 'What is your favourite outfit colour?' that there is a significant difference (chi-squared 8.5 and $\mathrm{P}=0.014$ ) in terms of following fashion trends. Far more respondents who chose beige as their favourite colour always or sometimes follow fashion trends, as seen in Table 9.

Table 9: Percentage of respondents who follow fashion trends

\begin{tabular}{|l|c|}
\hline $\begin{array}{c}\text { Respondents who prefer beige } \\
\text { Do you follow fashion trends when } \\
\text { choosing clothes? }\end{array}$ & Freq. [\%] \\
\hline Always & 33.30 \\
\hline Sometimes & 53.70 \\
\hline Never & 13.00 \\
\hline
\end{tabular}


We verified how people look for information regarding fashion using the question 'In what type of media do you read about the latest fashion trends?', and the answers, 'Online,' 'On the Facebook pages of different companies', 'In Slovenian magazines and online media' and 'In international fashion magazines', where we identified no significant differences regarding colour preferences.

We were, however, able to establish another criteria regarding people who prefer white. They tend to find most information regarding fashion trends online (chi-squared 7.88 in $\mathrm{P}=0.048$ ) (Table 10).

Table 10: How respondents look for information regarding fashion trends

\begin{tabular}{|l|c|}
\hline $\begin{array}{c}\text { Respondents who prefer white } \\
\text { In what type of media do you read } \\
\text { about the latest fashion trends? }\end{array}$ & Freq. [\%] \\
\hline Online & 73.90 \\
\hline $\begin{array}{l}\text { On the Facebook pages of different } \\
\text { companies }\end{array}$ & 13.00 \\
\hline $\begin{array}{l}\text { In Slovenian magazines and online } \\
\text { media }\end{array}$ & 4.30 \\
\hline In international fashion magazines & 8.70 \\
\hline
\end{tabular}

\subsubsection{Way of shopping}

We used different questions, applying different criteria, to examine how people shop for clothes. First, we were interested in whether people shopped exclusively via traditional methods, i.e. in clothing stores, or if they also bought clothes online. When crossing the answers, we found that half of those who prefer the colour white buy their clothes in both stores and online (chi-squared 3.7 in $\mathrm{P}=0.05)$. Individuals who preferred other colours still prefer to do most of their shopping in traditional stores (Table 11).

\section{Table 11: Different shops}

\begin{tabular}{|l|c|}
\hline \multicolumn{1}{|c|}{$\begin{array}{c}\text { Respondents who prefer white } \\
\text { Where do you buy your clothes? }\end{array}$} & Freq. [\%] \\
\hline In traditional stores & 50.00 \\
\hline $\begin{array}{l}\text { In both traditional stores and } \\
\text { online }\end{array}$ & 50.00 \\
\hline
\end{tabular}

We were also interested in whether respondents behaved differently regarding how often they bought clothes in correlation with their preferred outfit colour. We found no significant differences between how often respondents bought clothes (e.g. 'once a year', 'seasonally' or 'once a month') and their relationship to colours.

What is significant, however, is the manner and place of shopping for respondents who prefer pink and purple colours. These respondents differ from others in that they buy clothes in stores, where they look for the right clothes, try them on and make a purchase decision. The following findings hold true for the colour pink (chi-squared 8.16 in $\mathrm{P}=0.017$ ) (Table 12).

Table 12: Process of buying clothes

\begin{tabular}{|l|c|}
\hline \multicolumn{1}{|c|}{$\begin{array}{c}\text { Respondents who prefer pink } \\
\text { How do you buy clothes? }\end{array}$} & Freq. [\%] \\
\hline $\begin{array}{l}\text { Look for the right clothes in a store } \\
\text { and buy }\end{array}$ & 84.60 \\
\hline $\begin{array}{l}\text { Look for the right clothes online } \\
\text { and buy in a store }\end{array}$ & 3.80 \\
\hline $\begin{array}{l}\text { Try clothes on in a store and buy } \\
\text { online }\end{array}$ & 11.50 \\
\hline
\end{tabular}

We identified a similar pattern for the colour purple (chi-squared 15.3 and $\mathrm{P}=0.000$ ), as seen in Table 13 .

Table 13: Process of buying clothes

\begin{tabular}{|l|c|}
\hline \multicolumn{1}{|c|}{$\begin{array}{r}\text { Respondents who prefer purple } \\
\text { How do you buy clothes? }\end{array}$} & Freq. [\%] \\
\hline $\begin{array}{l}\text { Look for the right clothes in a store } \\
\text { and buy }\end{array}$ & 77.08 \\
\hline $\begin{array}{l}\text { Look for the right clothes online } \\
\text { and buy in a store }\end{array}$ & 7.40 \\
\hline $\begin{array}{l}\text { Try clothes on in a store and buy } \\
\text { online }\end{array}$ & 14.80 \\
\hline
\end{tabular}

\subsubsection{Relationship to shopping}

Shopping is an activity that fills many people with pleasure, while others think of shopping as a chore that must be completed as quickly as possible. Looking at it from a socio-analytical standpoint, shopping is a process in which a person is subject to different states of human behaviour. During that process, we can perceive behavioural expressions of love, sacrifice and dedication [14]. One of the aims of our study was to examine the link between the 
respondents' relationship to clothes shopping and their personal well-being.

Those whose clothing included beige or brown items enjoyed shopping much more than others. As seen in the Tables 14 and 15 , more than $50 \%$ of respondents who prefer the colour beige and $47 \%$ of those who prefer the colour brown stated that they like shopping. One third of each colour groups is neutral, while around $10 \%$ of respondents see shopping as a chore that they hate (see the tables below).

Table 14: Relationship to shopping

\begin{tabular}{|l|c|}
\hline $\begin{array}{c}\text { Respondents who prefer brown } \\
\text { What is your relationship to } \\
\text { clothes shopping? }\end{array}$ & Freq. [\%] \\
\hline I hate shopping & 12.50 \\
\hline I don't like shopping & 2.50 \\
\hline Don't care & 27.50 \\
\hline I like shopping & 47.50 \\
\hline I love shopping & 10.00 \\
\hline
\end{tabular}

Brown (chi-squared 13.3 and $\mathrm{P}=0.010$ )

Table 15: Relationship to shopping

\begin{tabular}{|l|c|}
\hline \multicolumn{1}{|c|}{$\begin{array}{c}\text { Respondents who prefer beige } \\
\text { What is your relationship to } \\
\text { clothes shopping? }\end{array}$} & Freq. [\%] \\
\hline I hate shopping & 1.90 \\
\hline I don't like shopping & 9.30 \\
\hline Don't care & 24.10 \\
\hline I like shopping & 51.90 \\
\hline I love shopping & 13.00 \\
\hline
\end{tabular}

Beige (chi-squared 13.8 and $\mathrm{P}=0.008$ )

\subsubsection{Shopping during sales}

While studying whether our respondents' shopping patterns change during sales, we determined that respondents who stated that their favourite colour is pink were those who enjoyed sales the most. As seen in the Table 16, the percentage of those who shop at normal times and during sales is far higher than that of respondents who only shop during sales. Due to the small sample size of answers, we combined the answers 'only during normal times' and 'during sales' into 'during normal times and sales' to arrive at a higher difference (chi-squared 7.3 and $\mathrm{P}=0.007$ ).
Table 16: Shopping during sales

\begin{tabular}{|l|c|}
\hline $\begin{array}{c}\text { Respondents who prefer pink } \\
\text { Do you buy your clothes during } \\
\text { sales? }\end{array}$ & Freq. [\%] \\
\hline During sales & 30.80 \\
\hline During normal times and sales & 69.20 \\
\hline
\end{tabular}

\subsubsection{Trying on clothes}

The process of shopping also involves trying on clothes and outfits. We therefore asked respondents if they always try on the clothes they are buying when shopping. Respondents who prefer the colour blue for their clothes are most thorough in this regard. A total of $60 \%$ of those respondents always try on an outfit, $23 \%$ sometimes try on clothes, and $14 \%$ said they never try on an outfit before buying it (chi-squared 10.5 and $\mathrm{P}=0.005$ ) (Table 17).

\section{Table 17: Trying on clothes}

\begin{tabular}{|l|c|}
\hline $\begin{array}{c}\text { Respondents who prefer blue } \\
\text { Do you always try on clothes you } \\
\text { want to buy? }\end{array}$ & Freq. [\%] \\
\hline Yes & 60.00 \\
\hline No & 14.00 \\
\hline Sometimes & 23.00 \\
\hline
\end{tabular}

\subsubsection{Shopping days for clothes}

We asked respondents which day of the week they shop most often. The following options were given as potential answers: 'from Monday to Thursday', 'Friday', 'Saturday', 'Sunday', and 'Not important.' The majority, or $75 \%$ of respondents, stated that the day was not important to them. The smallest percentage (2.5\%) said they prefer to shops on Sundays. When crossing the variables, we found that those who stated black as their favourite colour do not prefer shopping on Saturdays. As seen in Table 18 below, $91.4 \%$ of the aforementioned respondents do not shop on Saturday (chi-squared 6.2 and $\mathrm{P}=0.012$ ).

Table 18: Shopping on Saturday

\begin{tabular}{|l|c|c|}
\hline \multirow{2}{*}{ Shop on Saturdays } & \multicolumn{2}{|c|}{ Prefer black } \\
\cline { 2 - 3 } & No [\%] & Yes [\%] \\
\hline No & 75.90 & 91.40 \\
\hline Yes & 24.10 & 8.60 \\
\hline
\end{tabular}




\subsubsection{Financial means spent on clothing}

Frugal people prefer blue clothes, while wasteful people prefer white clothes. Taking into account the percentage of income spent on clothing, we found that there are only significant differences between the colours blue and white. The colour blue was chosen mostly by respondents who spend less than $20 \%$ of their income on clothes (chi-squared 7.92, $\mathrm{P}=0.019$; see Table 19). When white was given as the favourite colour, the opposite was true: there was a higher percentage of people who spend more than $20 \%$ of their income on clothes, as seen in Table 20. Far more respondents who spend more than $20 \%$ of their monthly income on clothes stated white as their preferred colour (chi-squared 10.19, $\mathrm{P}=0.006$ ).

Table 19: Percentage of income spent on clothes by those who prefer the colour blue

\begin{tabular}{|l|c|}
\hline $\begin{array}{c}\text { Respondents who prefer blue } \\
\text { How much do you spend for } \\
\text { clothes? }\end{array}$ & Freq. [\%] \\
\hline Less than 20\% & 62.00 \\
\hline Approximately 20\% & 18.00 \\
\hline More than 20\% & 20.00 \\
\hline
\end{tabular}

Table 20: Percentage of income spent on clothes by those who prefer the colour white

\begin{tabular}{|l|c|}
\hline $\begin{array}{c}\text { Respondents who prefer white. } \\
\text { How much do you spend for } \\
\text { clothes? }\end{array}$ & Freq. [\%] \\
\hline Less than 20\% & 40.00 \\
\hline Approximately 20\% & 26.10 \\
\hline More than 20\% & 33.70 \\
\hline
\end{tabular}

The survey offered respondents a table with prices for several different clothing items. The prices were divided into the following categories: up to $€ 20$, between $€ 20$ and $€ 40$, between $€ 40$ and $€ 70$, between $€ 70$ and $€ 120$, and between $€ 120$ and $€ 250$. Because some clothing items differ starkly from each other, two separate tables were made for both genders. For the purpose of interpreting the results, we pooled data into two groups: up to $€ 70$ and from $€ 70$ to $€ 250$ (Table 21). Men who chose white as one of their favourite colours for clothes shop in the lower price range of up to $€ 70$ (chi-squared 5.39 and $\mathrm{P}=0.020$ ).
Table 21: Price ranges of a man's suit

\begin{tabular}{|l|c|c|}
\hline \multirow{2}{*}{$\begin{array}{c}\text { Prefer } \\
\text { white }\end{array}$} & \multicolumn{2}{|c|}{ Price } \\
\cline { 2 - 3 } & Up to $€ 70[\%]$ & $\begin{array}{c}\text { From } € 70 \text { to } \\
€ 250[\%]\end{array}$ \\
\hline No & 35.30 & 68.30 \\
\hline Yes & 64.70 & 31.70 \\
\hline
\end{tabular}

We found a similar pattern among men who choose grey as one of their favourite colours. When purchasing a man's jacket, significantly more customers will buy in the lower price range of up to $€ 70$ compared with those men who did not state grey as a favourite colour (chi-squared 7.38 and $\mathrm{P}=0.007)$.

Table 22: Price ranges of a man's jacket

\begin{tabular}{|l|l|c|}
\hline \multirow{2}{*}{$\begin{array}{c}\text { Prefer } \\
\text { grey }\end{array}$} & \multicolumn{2}{|c|}{ Price } \\
\cline { 2 - 3 } & Up to $€ 70[\%]$ & $\begin{array}{c}\text { From } € 70 \text { to } \\
€ 250[\%]\end{array}$ \\
\hline No & 80.20 & 95.00 \\
\hline Yes & 19.80 & 5.00 \\
\hline
\end{tabular}

We can draw a conclusion with somewhat less certainty about the relationship to jacket prices for those women who shop in the lower price range compared with those women who did not state green as a favourite colour in the price range of up to $€ 70$ (chi-squared 3.71 and $\mathrm{P}=0.050$ ) (Table 22).

Table 23: Price ranges of a woman's jacket

\begin{tabular}{|l|c|c|}
\hline \multirow{2}{*}{$\begin{array}{c}\text { Prefer } \\
\text { green }\end{array}$} & \multicolumn{2}{|c|}{ Price } \\
\cline { 2 - 3 } & Up to $€ 70[\%]$ & $\begin{array}{c}\text { From } € 70 \text { to } \\
€ 250[\%]\end{array}$ \\
\hline No & 83.10 & 93.30 \\
\hline Yes & 16.90 & 6.70 \\
\hline
\end{tabular}

\section{Discussion}

We can verify the often stated claim that colours are extremely important in our daily life. On the one hand, colours have a significant impact on our wellbeing, while on the other hand, our own personality and behaviour influence the way we choose colours. 
We were able to reach some definitive conclusions with this study.

We were partially able to verify the hypothesis about a statistically significant relationship between demographic characteristics and a person's preference for a certain outfit colour. Demographic characteristics were proven to be insignificant in terms of the behaviour of different segments, except when genders were compared. Here, we were able to identify certain differences that are undoubtedly linked to historic memory and upbringing: boys prefer blue, while girls prefer pink. Other characteristics, such as age, education and income cannot be correlated sufficiently to the selection of the colour of one's clothes to be deemed significant.

Moreover, while attempting to prove the hypothesis about a statistically significant relationship between behavioural characteristics and the preference for a certain outfit colour, respondents were mostly homogeneous in terms of the style of clothing. We identified no significant differences or changes. More conclusions can be derived from variables such as the relationship to clothes and fashion, the way people shop and the amount of financial means that individuals set aside for clothes. The same holds true for the importance of the clothes in the eyes of the consumer. We likewise identified no significant differences through these answers in terms of colour preferences for clothes.

A higher percentage of those who prefer the colour beige tend to follow fashion trends than others. The colour white is associated with those who follow fashion trends online. In terms of the manner of shopping, the colour white is also more closely linked to the online world than other colours.

People who prefer the colours pink and purple tend to shop for the most part in stores, while those who prefer the colours brown and beige enjoy shopping more than others.

People who prefer the colour blue are the most thorough when trying on clothes, while people who like black do not like to shop on Saturdays. Respondents who prefer the colour blue stand out in terms of spending money on clothes, while those who prefer white are more wasteful. When analysing the amount of money that respondents usually spend on clothes, we found that those who prefer blue buy clothes at the lower end of the price range, while the colour grey is associated with shopping for suits. A higher percentage of those who prefer the colour grey buy suits in the lower price range. The same holds true for the colour green among women: a higher percentage of women who prefer the colour green buy jackets in the lower price range.

\section{Conclusion}

All of these findings confirm our hypotheses that colours are closely linked to the behaviour of individuals. Nevertheless, the findings and results of our survey raise new questions. First, what is the relationship to financial means among those who wear blue and white clothing? Are they thriftier when spending on the blue part of an outfit than the white part? Other questions also arise. Because most of these links are made on a subconscious level, it makes sense to consider a more complex research methodology.

We also noted at times that the small sample size of respondents was problematic, as the crossing of different variables did not give satisfactory results, which forced us to combine certain variables.

The results and findings of this study can serve as guidance in research of the relationship between colours and consumers' characteristics. Above all, the authors of this article deem it necessary to determine how the selection of preferred colours actually works. Is it a consequence of historic determinants, fashion and marketing communication, or other, more rational and computable motives that are associated with an individual's personality? We also believe that it would make sense to include different clothing brands in the study. This research is limited by the fact that it only looks at one country, and thus one culture, and we believe a larger sample size would provide better results.

\section{References}

1. PETERSEN, Gerda. EC56-411 color for your clothes. Historical materials from University of Nebraska-Lincoln. Extension Paper, 1956, 3309 [online], [accsessed March 5, 2017]. Available on World Wide Web: <http://digitalcommons. unl.edu/extensionhist/3309>.

2. RUI, Gong, QING, Wang, YAN Hai, Xiaopeng. Investigation on factors to influence color emotion and color preference responses. Optik-International 
Journal for Light and Electron Optics, 2017, 136, 71-78, doi: 10.1016/j.ijleo.2017.02.026.

3. CLARKE, Tom, COATALL, Alan. The emotional connotations of color: a qualitative investigation. Color Research \& Application, 2008, 33(5), 406-410.

4. XIAOFENG Jiang, LIU, Guoliang. The influence of color brightness on the perception of clothes gorgeousness. IEE $10^{\text {th }}$ International Conference on Computer-Aided Industrial Design \& Conceptual Design, 2009, doi: 10.1109/CAIDCD. 2009.5374987.

5. BENGTSSON, Matilda. Color adjustment of digital images of clothes for truthful rendering. Halmstad : University, 2016, 34p.

6. JABBAR, Zeenat, BALDWIN, Lynne. Developing brand personality through colour construct - a conceptual investigation [online], 9 p. [accessed 25. 09. 2017]. Available on World Wide Web: <https://marketing.conferenceservices.net/resources/327/2958/pdf/AM2012_ 0277_ paper.pdf $>$.

7. SHIN, Meong Jin, WESTLAND, Stephen, MOORE, Edel M., CHEUNG, Vien. Colour preferences for traditional Korean colours. Journal of the International Colour Association, 9 48-59.

8. ELLIOT Andrew, MAIER Markus, MOLLER Arlen, FRIEDMAN Ron, MEINHARDT Jorg.
Color and psychological functioning: the effect of red on performance attainment, Journal of Experimental Psychology: General, 2007, 136(1), 154-168, doi: 10.1037/0096-3445.136.1.154.

9. MADDEN, Tomas, HEWITT, Kelly, ROTH, Martin. Managing images in different cultures: a cross-national study of color meanings and preferences. Journal of International Marketing, 2000, 8(4), 90-107, doi: 10.1509/jimk.8.4.90.19795.

10. SHIN, Meong Jin, WESTLAND, Stephen, MOORE, EDEL M., CHEUNG, Vien. Colour preferences for traditional Korean colours. Journal of the International Colour Association, 2012, 9 48-59.

11. OKAN, Akcay, DALGIN, Muhammed H., BHATNAGAR, Swati. Perception of color in product choice among college students: a crossnational analysis of USA, India, China and Turkey. International Journal of Business and Social Science, 2011, 2(21, Special Issue), p. 42.

12. BURNS, Alvin C., VEECK, Ann F., BUSH, Ronald F. Marketing research. $8^{\text {th }}$ edition. London, etc. (Global edition) : Pearson Education, 2017.

13. PISANI, Lea. Ravni oblačenja: $z$ nasveti za goste na televiziji, pogovor za službo, pogrebno slovesnost, poroko, maturantski ples, šolo. Ljubljana : Lea Pisani, 2016, 157 p.

14. MULLER, Daniel. A theory of shopping. Cambridge : Polity Press, 2005. 